\title{
Joshua Mewburn - accidental New Zealand pioneer of 1833 and Pākehā-Māori
}

\author{
Ian G. Macdonald
}

\begin{abstract}
There are Mewburns in New Zealand today, but they are not related (other than perhaps back in the fourteenth century) to the first Mewburn to come to the islands. He was Joshua Mewburn (1817-c.1855). Joshua arrived in New Zealand first in 1833, an early, pre-colonial date so of particular historical interest. He returned to England in 1841, then shipped back again to New Zealand in 1842 on the Jane Gifford, the first ship to land official colonists, and is believed eventually to have died there. We know something of his exploits and life through court records and newspaper items, and through the journal of a voyage. It seems that he became what is known as a Pākehā-Māori. Joshua was robbed and abandoned in 1833 at the Bay of Islands, then taken in by Māori tribes where he may have lived for up to eight years, unusually, having his face tattooed during that time. He eventually returned to living with the Māori, but that last phase of his life is more obscure. This paper seeks to unravel some of his life and doings, and determine his place in early New Zealand colonial history. However, key aspects of his story remain intriguingly mysterious, so undiscovered sources in New Zealand archives may contain further clues.
\end{abstract}

\begin{abstract}
Origins
Mewburn is a rare name from north-east England - primarily the Cleveland area of North Yorkshire. Their genealogy has been well studied, and a tree for all the Mewburns can be found at the Mewburn and Meaburn website, supported by the Guild of One-Name Studies, ${ }^{1}$ while brief family history details can be found on a Mewburn \& Meaburn site. ${ }^{2}$ However, a few early Mewburns were also found in London and from them there developed, in the late eighteenth century, a line of silversmiths initiated by the noted maker John Mewburn (1762-1830), ${ }^{3}$ a fine silversmith and a Liveryman of the Goldsmiths' Company whose work commands high prices today (see Figure 1).
\end{abstract}

Joshua was one of the silversmithing line but chose not to enter that profession, becoming (briefly) a gas fitter, then a mariner, then a 'Māori', a tobacconist, and, occasionally, a showman before returning to Māori life, sojourning in Chile, and ultimately ending his days in Māori society. He may have lived the most exotic of the Mewburn lives. This line of Mewburns became extinct in the generation after Joshua.

Joshua was born on 27 March 1817 at Baldwin Street, Finsbury in London, ${ }^{4}$ and was baptised on 3 March 1817 at St Luke, Old Street. ${ }^{5}$ He was the eldest son of Henry John Mewburn and his wife, Jane Ramsey. Henry John is listed in the Freedom Index as becoming a Freeman of the Goldsmiths' Company on 5 February $1817 .{ }^{6}$ Henry worked for the Goldsmiths' Company and became the weigher (the most senior of the working roles) at the Assay Office. Craft life evidently did not appeal to Joshua and, unlike his younger brothers, he did not pursue silversmithing, but went to sea as a ship's boy when he was about fourteen. A later entry in the Register of Merchant Seamen from 18451854 lists him as "Josh Mewburn - Shadwell", with Ticket 244380. ${ }^{7}$ He escapes notice in formal UK records until 1865 in the Probate Calendar. ${ }^{8}$ Here we get: 
Letters of Administration of the Personal estate and effects of Joshua Mewburn late of New Zealand Bachelor [in fact an error, he did marry but was a widower by this date, and may also have had Māori wives] deceased who died in or since 1854 at New Zealand aforesaid were granted at the Principal Registry to Sarah Elizabeth Ashley (Wife of James Ashley) of the Old Eagle Camden Town in the County of Middlesex the Sister and one of the Next of Kin of the said Deceased ...

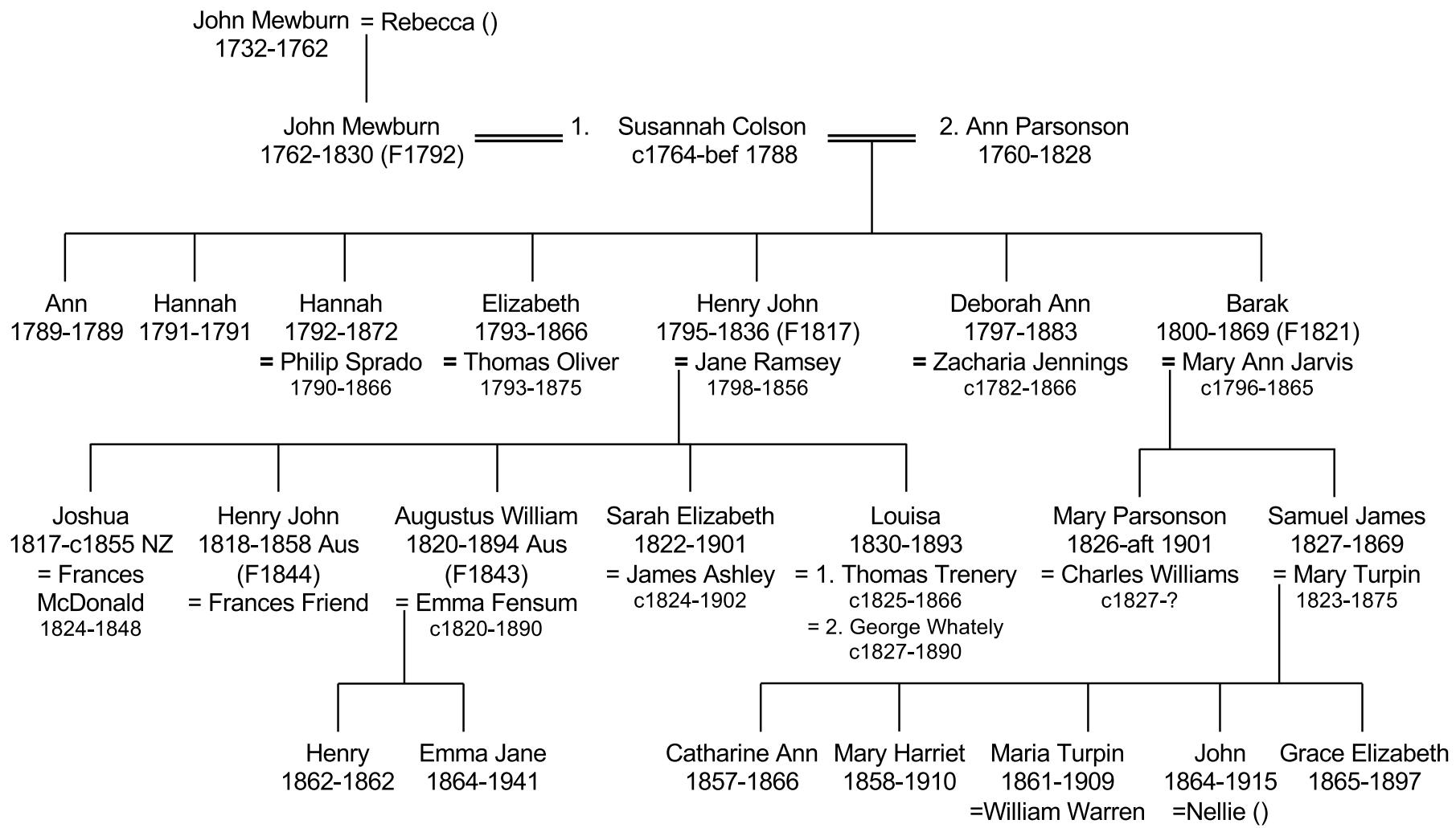

Figure 1. The Mewburn London silversmith line (with Freedom dates).

This is a remarkable listing, since his death is not certain but is being presumed. Papers at The National Archives, Kew, which lead up to probate, state that: "In the month of January 1833 Joshua Mewburn who lived at Matson's Cottage, Kingsland Road in the County of Middlesex [the family home, where John Mewburn lived] left England for New Zealand." ${ }^{9}$ This is somewhat misleading, since Joshua had returned briefly to England since that time, so his family did know rather more about his life. Court papers from 1865 state that he returned to England on 3 April 1841, although he has not been found in the census that took place on 6 June. He had been away for eight years and three months, so at that point had spent a little less than eight years in New Zealand, given the journey times.

\section{The exploits of Joshua}

Joshua did not write about his experiences, but was written about on his return to England. Our knowledge of his first eight years as a PākehāMāori comes largely from a newspaper article in The Times on 11 November 1841 (with the common misspelling of Newburn). ${ }^{10}$ Later we find he was displaying himself before the public as a spectacle for their entertainment so we must assume that this published account combined a desire on Joshua's part to market himself with a desire on the journalist's part to pander to conceptions of what the public wished to hear about life in a land of "savages". The use of stereotyping, hyperbole and the stoking of prejudice was almost inevitable. The article was syndicated and appeared in a great array of newspapers and other publications across England, Wales and Ireland in the following months. It was eventually printed in The Courier at Hobart in April $1842^{11}$ and in The Colonial Observer at Sydney in September $1842 .{ }^{12}$ It was even reproduced 140 years later in the Whakatane and District Historical Society's Historical Review. ${ }^{13}$ 


\section{AN EXTRAORDINARY CASE}

The following narrative, relating to Joshua Newburn, who has recently returned to this country, after having been captured by the natives of New Zealand, and after having served for nearly nine years and a half under chiefs of various tribes, during which period he underwent the cruel torture of tattooing, is authentic, and may be depended upon. There is something so truly extraordinary in the history of this young man's life, during his nine years and a half's residence in the interior of the island of New Zealand, that a few observations relating to him cannot fail to prove extremely interesting.

Joshua Newburn is the eldest son of the late Mr. John Henry Newburn, for many years a freeman of the Worshipful Company of Goldsmiths, in the City of London, and was born in the parish of St. Luke, on the $27^{\text {th }}$ of March, 1817. His family are still living in that parish in respectable circumstances. He received a plain education at an Hoxton academy (Gloucester House), under a Mr. Pearce, and was afterwards apprenticed to a gas-fitter in the city; but his inclinations being seaward, his father caused his indentures to be cancelled, and on the $27^{\text {th }}$ of February, 1832, he was articled for the term of three years to a Captain Plant, master of a whaler bound to the South Seas, named the Marquis of Lansdowne. After a voyage of three months and fifteen days from the date of leaving Portsmouth, the ship reached the Bay of Islands on the New Zealand coast, where she brought up; and young Newburn who was then but 15 years of age having suffered much sickness on board, obtained leave to go ashore to seek medical advice. As there were several canoes manned with natives around the ship, trading with the crew, Newburn took the advantage of bargaining with a rungateree, or head boatman, to take him ashore; but after they had left the ship, instead of the men rowing into the mouth of the harbour to the English settlements, they made away for a sandy beach at some distance off, and, having dragged him on shore, they stripped him quite naked, beating him at the same time with their paddles, till they left him insensible; they then took to the canoe and made off. As soon as he had partially recovered from the effects of their violence, he wandered about the island in quest of a human habitation, desirous if possible, of alighting upon some white man. This he continued to do for two days and nights, making the best of his way through forests of fern, breast-high, which (he being quite bereft of clothing) shockingly chafed and lacerated his body. On the third morning, as he sat under a tree, famished with hunger and exhausted with fatigue, he was perceived by two native youths, the sons of a chief living hard by, who, pitying his condition, conducted him to the hut of their father, who was lying sick upon a mat. Seeing that he (Newburn) was destitute of clothing, he furnished him with an old pair of canvas trousers, and a tattered shirt, and having afforded him such refreshment as his circumstances would admit of he sent him to a neighbouring chief, who, he said, would use him well.

To follow the life and adventures of this young man, from that period up to the time of his quitting the country for England; to detail the checkered circumstances he met with during the nine years and upwards he served with various tribes of the island; to depict the scenes he witnessed, the imminent perils he encountered, the severe, almost incredible hardships he endured, the dreadful privations he underwent, and the miraculous escapes he experienced, would occupy the space of a large volume. He is now in London, and although he speaks his native language correctly, yet it is with difficulty that he at times can find words wherewith to express his ideas. His body is cicatrized in many places from the wounds he has from time to time received from the spears and knives of the natives whilst he was engaged under different chiefs, contending with militant tribes; and his face has undergone the horrible operation of tattooing, which gives him the appearance of a New Zealand chief. Although he is now only in his twenty-fifth year, from the acute sufferings he has undergone (having been at one period exposed for 14 months in the bush), he appears considerably older, and his constitution has been so severely shattered that it is quite impossible that he could have subsisted another year had he remained on the island. He speaks the New Zealand language with the utmost fluency, and became ultimately so thoroughly initiated into the ways, habits, and manners of the natives, that they identified him with themselves, and styled him by a term of distinction, "Mootooah," which means "the tattooed spirit." In describing the scenes he witnessed among the tribes he is exceedingly simple, and imparts what information may be sought of him in a very clear and artless manner.

He states that the first instance of human butchery he witnessed in the island was shortly after his arrival. A canoe landed a crew of natives whilst he was standing on the beach near a pah, or village, named Korozalka; he perceived two females among them, who were particularly good-looking; among them was a very powerfully made man, who held a tomahawk in his hand, and who followed close upon the heels of the women as they proceeded on the beach, when he suddenly stepped before them, and with one blow with his weapon nearly severed the head of one from her body; he afterwards performed the same tragical operation upon the other female, and left them weltering in their blood upon the beach. As soon as he had sufficiently collected himself he ran home to the pah, appalled at what he had seen, and communicated, as well as he could, the circumstances to his chief, fearing that himself and his tribe might be beset by the party. Upon inquiry, however, it was discovered that the women were the slaves of a neighbouring chief, who had given his command that they should be tomahawked out of his own settlement for their disobeying his orders with regard to his children. He moreover, states that, some time afterwards, when he was at a pah called "Warakaika," he was witness to one of the most revolting acts of butchery that it could be destined for the human eye to behold. The chief of the tribe under which he served had waged war with the chief of another tribe located in a pah a short distance off them. They sallied forth just before daybreak, armed with muskets, spears, and tomahawks (for the natives, he says, when they want to surprise an enemy, consider this the most seasonable time, entertaining an idea that sleep lays its hand more heavily upon the slumberer at that particular period than any other that is appropriated to repose); and the chief having fired off his musket on their arrival at the pah, as a signal for commencement of hostilities, they all began the war-dance, which was kept up for about two minutes, when they fired their muskets into the mat-houses of the enemy, and then took to their spears and tomahawks, and after a desperate conflict the pah surrendered, and the tribe were made prisoners and bound. Then the chief of his tribe went round to each prisoner and despatched the whole of them, one after another, by striking them on the head with his tomahawk. He, moreover adds, that there were among the number of the captives one chief of high rank, as also a seer or diviner, and a noted warrior, who were all three seated upon a rush mat by themselves. The chief of his tribe advanced towards them, and with his tomahawk tapped their several heads and drank the blood as it ran from them. Another man of his tribe took out the eyes of the wretched victims and ate them raw, life not being out of the former. They finally cut off their limbs and quartered them ready for the oven. 
But the most dreadful feature in this act of massacre was that of a man and woman bound together, the former being the son of the opponent chief of the pah, the latter his wife, who held a child, about nine months old, in her arms. This young warrior had murdered, with his own hand, several of the tribe to which he (Newburn) belonged; and having dragged the woman, after having untied her from her husband, into an adjoining compartment, and after having committed the grossest acts of violence upon her, they tore the infant from her protection, and taking it up by the legs battered its head against the sides of the hut. As to the unfortunate husband, they cut slices of flesh from his body, and thrusting the same into his mouth, asked him if it "was good, and tasted well." He stopped in this place for two days with his tribe, during which time they were employed in cooking their enemies, in such a manner as to keep them for some length of time. This process is performed by first cutting away all the flesh from the bones, and separating the lean from the fat: the fat is fried in earthen vessels to yield a lard; the lean is baked in the oven. The latter is then put into calabashes, and the fat poured over it; by this means the meat will keep sound for upwards of 12 months.

The language of the time is wordy and the article is not always accurate as to verifiable facts. The Marquis of Lansdown set out in 1833 rather than 1832, so Joshua was away for eight rather than nine years. For the rest, it is hard to judge to what extent we can rely on the accounts of warfare and cannibalism. After commenting on "the most revolting acts of butchery that it could be destined for the human eye to behold", we are treated to a detailed account revelling in that revoltingness. This is a journalist looking for headlines. He succeeded.

Hazel Petrie has suggested that Joshua's service with "various tribes" is indicative of having been enslaved. ${ }^{14}$ It may be that he was passed around for the entertainment of the tribes. The journalist does not describe Joshua as a slave but as having "served", and for performances he was described as having been a "captive". Clearly, it would not have sat well with Joshua's desire to appear as a "Māori chief" in England if he had been described as a slave. The possibility of chiefly status will be examined later.

By living with the Māori, Joshua became what is called a Pākehā-Māori (broadly, a white male European living as a Māori). Trevor Bentley notes in his PhD thesis, Images of Pakeha-Maori, that:

Pakeha-Maori were expected to "perform" for their tribe and for European audiences, alternately explaining the worlds of Europe or Aotearoa to spellbound listeners. ... For Pakeha-Maori, their narratives became the drama of their lives and were theatres for their descriptions of self in early New Zealand. ... When the tattooed Pakeha-Maori Joshua Newborne was arrested for drunkenness in London in 1842, the Illustrated London News made much of his "war-dance" and "screeching". ${ }^{15}$

Several of the Pākehā-Māori discussed by Bentley lived with the tribes for only a matter of months. Joshua's initial eight years, and the many more between when he returned in 1842 and his possible death in 1855, was exceptional in these early years, perhaps surpassed only by Jacky Marmon who arrived fifteen years earlier but lived until $1880 .^{16}$ Bentley, however, found out nothing else about Joshua. It is a tragedy that Joshua's experiences were not recorded more completely.

Seven months after the Times article, on 21 May 1842, the Illustrated London News carried a piece on him following a court appearance, having been drunk in the streets of Hoxton. ${ }^{17}$ Apparently, he had been "exhibiting as a New Zealand chief at places of public amusement". This piece, too, was eventually relayed to New Zealand and appeared in the New Zealand Colonist and Port Nicholson Advertiser. ${ }^{18}$ It contains a comical cartoon of a wild Joshua battling with two policemen.

\section{Worship Street}

On Tuesday, Joshua Newburn, a young man about 25 years of age, whose swarthy visage was tattooed like a native of New Zealand was placed at the bar before Mr. Bingham, upon a charge of being drunk and assaulting the police. Mr. Bingham asked if he understood English? Sergeant Lambert said the prisoner was a Londoner, born near St Luke's church; but it appeared from his own account of himself, that he had been made prisoner by the New Zealanders, and had passed several years amongst them, after having consented to be tattooed like one of themselves. The prisoner's narrative was to the following effect: - About 11 years back, he was a boy on board a whaler called the Marquis of Lansdowne, but during an outward voyage was seized with typhus fever, and put with others on board a schooner, to be conveyed to port. He and his companions, however, fell into the hands of savages, by whom they were all, in a short time, destroyed and (we understand him) eaten, except himself; but he having been reserved till the last, his life was spared, upon his consenting to be marked and to live with them. He accordingly underwent the painful process of tattooing, preparatory to which, however, they administered to him some narcotic to render him less sensible to the pain of the operation. He was with them nearly ten years altogether, and frequently engaged with them in their battles with hostile tribes, after which contests the prisoners were commonly killed and eaten by the native captors. He had no wife among them, but had married since his return to England, and has lately been exhibiting as a New Zealand chief at places of public amusement. A police constable of the $\mathrm{N}$ division stated, that while on duty at a late hour on Monday night, he heard an extraordinary kind of yelling in Hoxton Square, and proceeding to the spot, found the prisoner dancing about, and disturbing the neighbours with his wild and terrific cries. The prisoner, who was drunk, 
instead of desisting, and going away as desired, set the witness and other constables at defiance, and after a violent resistance, was lodged in the stationhouse. Sergeant Lambert said, that he was exceedingly violent at the station-house, and vowed vengeance against the constable who took him there, threatening to feast upon his heart, and "lick his chops with his blood;" and during the greater part of the night he appeared to be dancing his war dance in the cell, and screeching at the top of his voice. The prisoner, whom the New Zealanders had named "Moika Makoura." The meaning of which he stated to be "The tattooed spirit," now expressed his sorrow for his disorderly conduct. He very seldom drank spirits, but when he did, he said it made him quite wild; and a friend whom he met on Monday had made him drink some. Mr. Bingham told him he must be aware that such wild conduct could not be permitted; and if he got drunk and committed himself even in New Zealand, he would have to bear the consequence of his misconduct. He must pay five shillings for getting drunk. The prisoner, who had no money, was locked up until the close of business, and then discharged.

This account gives a very different description of how Joshua fell into the hands of the Māoris. There are also discrepancies in timing between this and the probate records. If he had set out eleven years earlier, then that would have been 1831 rather than 1833 . The latter date is confirmed in the listing of the Marquis of Lansdown on the University of Hull's database of whalers. She was 225 tons, built in Calcutta in 1825. She set out on 1 February 1833 (under Captain Plant; owner Joseph Somes) and returned on 20 December 1836 with some 500 casks of whale oil. ${ }^{19}$ The ship's stay in New Zealand waters is further confirmed by Rhys and Chisholm in the Bay of Islands Shipping Arrivals and Departures, where it is listed as "July 1-13; Marq. of Lansdown, London; Plant; London to fishery; no cargo; source NSW V\&P, p. 169."20

Evidence of Joshua "exhibiting" himself comes from a playbill for the Royal Victoria Saloon, Ironmonger Row, by St Luke's, Old Street (coincidentally where he had been baptized), on 28 March 1842. ${ }^{21}$ It offered a "Second Week of Moko Wairua!" with the illustration shown in Figure 2. Where else he may have performed is not known.

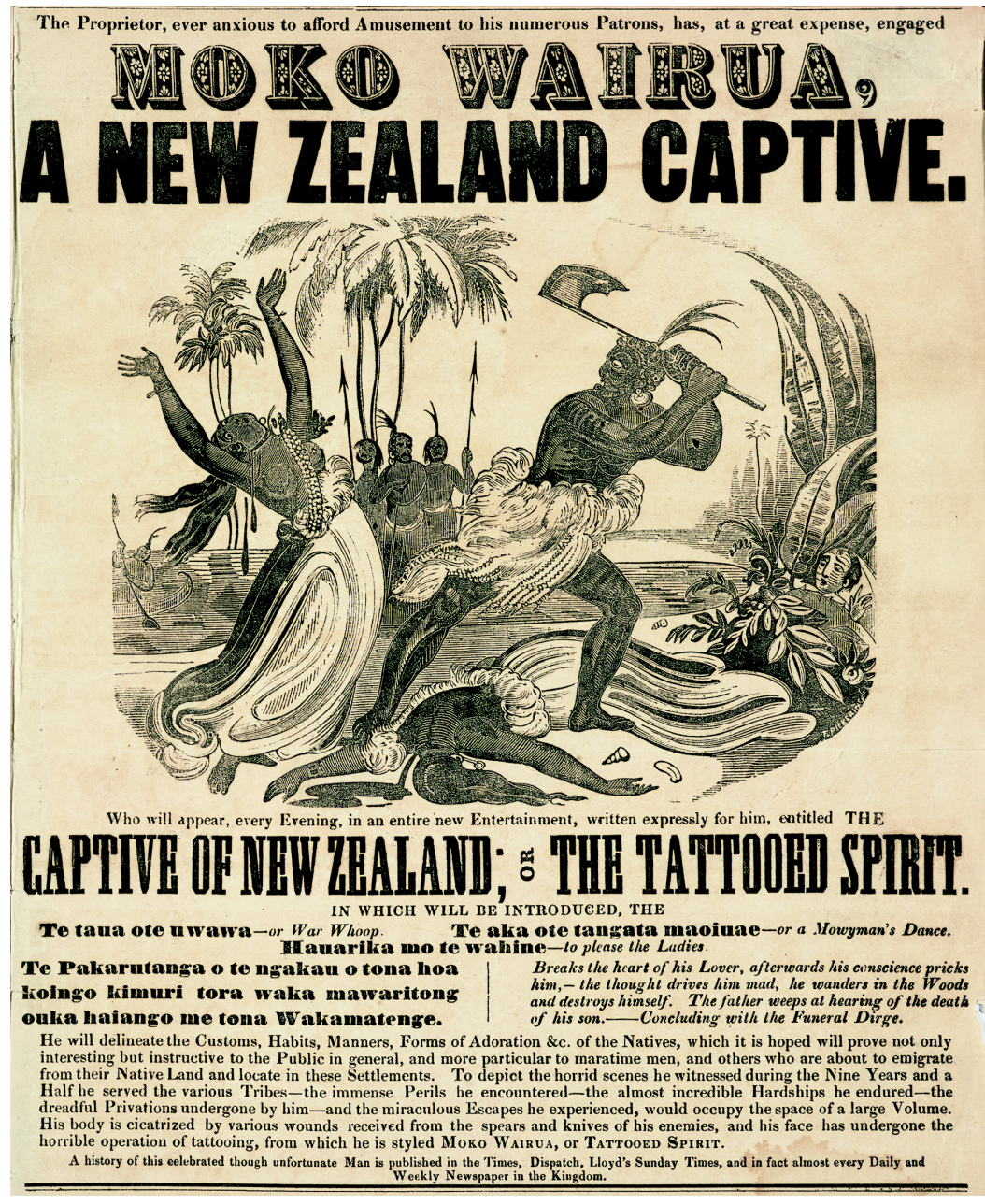

Figure 2. Joshua on the London stage. Ref. B-039-022, with permission from the Alexander Turnbull Library, Wellington, New Zealand. 
How Joshua had returned to England is not certain. Court papers from probate in 1865 state that he returned on 3 April 1841. Lloyd's List shows a ship, the John Renwick, under Captain Morgan arriving at Gravesend on that date from Sydney, New South Wales. ${ }^{22}$ It is the only contender (ships arriving directly from New Zealand were rare) but we do not know where Joshua joined that ship (whether it called at Auckland or whether Joshua had somehow made his way to Sydney). The only slight reason to question the return date is that, as mentioned above, he has not been found in the 1841 census held on 6 June that year (but poor indexing may have made him invisible). However, it seems certain he must have arrived earlier than the census because he was involved in a business failure in August.

It is hard to imagine him having returned with any resources but there was the $£ 100$ bequeathed to him on the death of his father in 1836 , and still in trust. ${ }^{23}$ That may have been used as surety to take a stake in a tobacconist's business. The venture, though, did not go well, as an entry in the London Gazette shows:

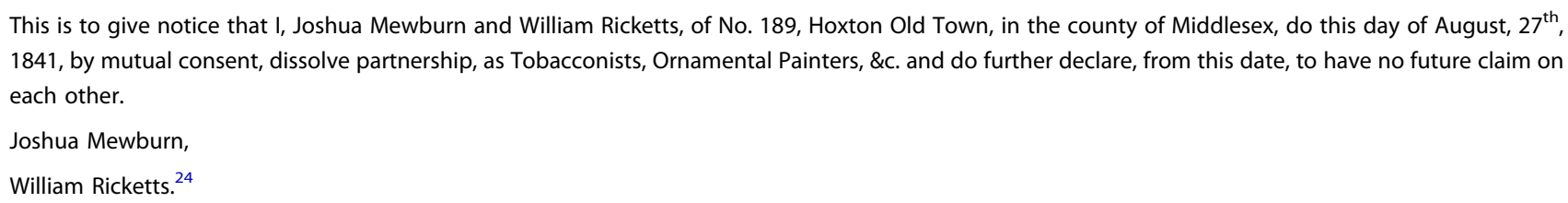

This business presumably started and ended very quickly, as it was less than six months since Joshua's arrival back in England. A further two months later, on 20 October $1841,{ }^{25}$ Joshua married Frances Ellen McDonald (she was clearly not dissuaded by his tattooed face, which must have been particularly exotic for the time). They were both then living in Bermondsey Street.

British sovereignty over New Zealand had been established in 1840 and specific efforts began to be made to encourage colonization. Paisley, at that time, was the most depressed town in Britain, with the virtual collapse of the weaving trade, and the Paisley New Zealand Emigration Society was formed ${ }^{26}$ (from the less successful Paisley Canada Emigration Society) to facilitate passages, starting with two ships - the Duchess of Argyle and the Jane Gifford - given government support in April. ${ }^{27}$ However, they struggled to fill the places since the handloom weavers were too poor even to be able to kit themselves out for the voyage and their sedentary occupation did not fit them for the new life. ${ }^{28}$ Opportunities were advertised in newspapers and presumably came to Joshua's attention. Each ship had its own advertisement repeated regularly in, for example, the Glasgow Herald: ${ }^{29}$

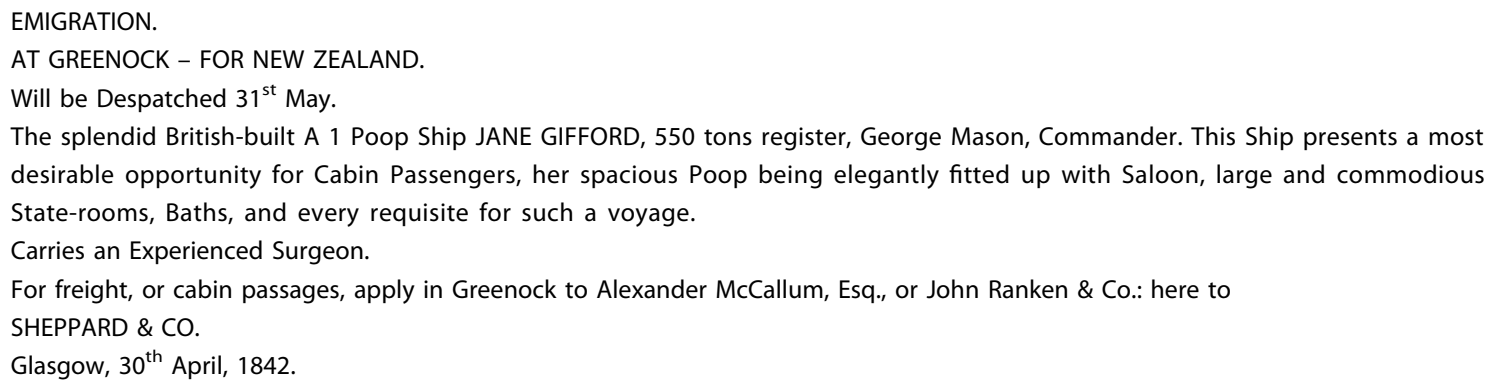

There are then transcriptions showing a record of "Joshua Mowburn" returning to New Zealand on the barque Jane Gifford. ${ }^{30}$ It left Glasgow on 18 June 1842 (though listed as 19 June), ${ }^{31}$ with a largely Scottish collection of emigrants, and reached Auckland on 9 October that year. ${ }^{32}$ The GENi website ${ }^{33}$ indicates that Joshua was twenty-five and that he was with Frences [sic] E Mowburn, aged seventeen - so there can be little doubt that it was them. Joshua did not have the privilege of a state room and bath. We are particularly fortunate since there is a written account of the voyage of the Jane Gifford by one of the passengers, Robert Graham. ${ }^{34}$ This provides insight into conditions during the passage but, importantly, also has comments about Joshua and his behaviour. These provide a possible insight into his attitudes and motivation. The entries relating to Joshua are shown in Figure 3. (This transcription is of a typed transcript, created at Auckland Museum in 1957 from the manuscript original.)

It appears, from other parts of the commentary, that there were several marriages of convenience among the couples on board, all seeking by them to gain a free passage. In Joshua's case the marriage took place eight months prior to the voyage. If he really did it to secure a passage then he was guilty of cynical premeditation since the Jane Gifford opportunity had not then even been advertised. 
p. 25

Monday $11^{\text {th }}$

...There is a man on board (sic) tattooed after the same style as the Newzealanders he was 9 years in Newzealand (sic) and has married an English woman merely to get out as a single man could not get a free passage easily, last night they

p. 26

quarrelled (sic) amongst themselves and he told her plainly his object for marrying her and that he has a wife in Newzealand (sic) they are a very unhappy pair, I think the one is as bad as the other, Dancing and singing this evening

p. 72

a beautiful evening we were up latter than usual some of the passengers were dancing till about $1 / 2$ past 10 p.m. when Joshua Mewburn the person that is Tatooed (sic) after the Newzealand (sic) style came amongst those that were dancing for the express purpose of annoying them when he was ordered by the mate to keep at a respectable distance he did go away but soon returned when the Mate ordered him below he was not for going but the Mate pushed him out of the road in a few minutes afterwards he came back and spoke in abusive language Mate and even lifted his hand to strike the Mate when the Mate instantly knocked him down and the Newzealander (sic) (as he is generally called) cried out with a voice like Thunder (A Bloody Mutiny on board the Bloody ship) This made wives women \& chldren run seeking for a place of refuge the Captain soon was on the spot and saw that the Newzealander (sic) was evidently tipsy he ordered him below and told him that

p. 73

the next time he quarrelled in this ship he would order him to be put in Irons the Newzealander (sic) went below but only remained a few minutes when he came up on deck and was making a terrible noise when the mate and two of the constables put him below by force he then theatened to take the Mates life set the ship on fire \&c. when the captain was informed of him using such threats he ordered him to be put in irons which was soon acomplished (sic) he after- wards lay very quiet and continued so the whole night...

p. 76

... the Mate went to see the Newzealander (sic) this morning but as the spirits was not quite out of his head he still threatened vengance (sic) the Captain ordered a place to be cleared for him in the hold and he was put down with his hands fixed behind his back with Irons and also his legs fixed closely together by the ancles (sic) a very tiresome position to be confined and locked down into a dark hold ordered to be fed on a biscuit a day $\&$ half a pint of water I should think not a very enviable situation...

p. 78

Saturday $3^{\text {rd }}$ Sept.

... the Newzealander (sic) is getting very penitent and says he is the most harmles (sic) man in the ship...

Figure 3. Excerpts from a written account of the voyage of the Jane Gifford.

Drink, as in London, seems to have affected Joshua badly. It is uncertain whether his comments while under the influence can be relied on, so his claim to having a wife in New Zealand may be doubted and conflicts with testimony from his London court appearance. It may just have been a way to hurt his wife of convenience. However, we may surmise that Joshua was motivated principally by a desire to return to New Zealand, where many of his formative years had been spent. It seems unlikely that he had much desire for employment in developing the colony that was the ostensible reason for his being given a passage. Did his ambition extend any further than simply returning to Māori society? We cannot know. 
The marriage did not last and Frances returned to London, either disillusioned or abandoned. When she returned has not been established (though an old history discussed below provides a slight clue), but we have a burial record for Frances Ellen Mewburn, aged twenty-three, back at Shoreditch in $1848 .^{35}$ They had no children.

The next evidence we have relating to Joshua comes after his mother's death in London in 1856 . His absence caused difficulties for the family in gaining probate for his father's estate (which was retained by trustees for the use of his widow while she was still alive), since Joshua remained a beneficiary. His exact whereabouts was unknown and a major search had to be carried out by his brother, Henry John. Letters were sent to various people in New Zealand (all recorded in court papers at The National Archives, Kew) and an advert was placed in the Sydney Morning Herald ${ }^{36}$ (since they were also looking for Joshua's brother William Augustus who was in Australia). The first part of the advert deals with Joshua:

$£ 10$ REWARD - Information wanted of Joshua MEWBURN, who in February, 1848, was living with Jose Vadibia Fabrica de Cohere Caile Dalesibarratillos, Santiago, Chile, and has not since been heard of. He had lived several years previous in New Zealand, and was tatooed all over the face: known mostly in that country and many islands in the South Seas, as Moka Wairura, had fair complexion, dark blue eyes, and black hair, born in London, 1817: was known to Captain Webster of New Zealand.

This offers some remarkable comment but requires interpretation. The advert is quite specific about Joshua living in Chile in 1848. Chile's independence from Spain had been recognized only in 1844 so it might have been seen, by an adventurous soul such as Joshua, as a place of opportunity in 1848. Ships from Australia and New Zealand were by then taking advantage of the prevailing winds and picking up mineral cargoes from Chile and Peru on their way back to Europe, ${ }^{37}$ so it would not have been difficult for Joshua to make his way there.

Despite the advert's lack of punctuation, it seems he was with a Jose Vadibia. Nothing has been found out about him, even if the name is correct - Valdivia is a recognized name while Vadibia is not. Indeed, Santiago was founded by Pedro de Valdivia in 1541 and Chile has a city called Valdivia. Fabrica de Cohere translates simply as the Cohere factory - Cohere being perhaps the name of its owner. Caile Dalesibarratillos probably should be Calle de los Barratillos. Barratillos means a street market or secondhand goods shop. That street was present in Santiago and is said to have gained its name "from the clothes vendors and footwear sellers that were established" there ${ }^{38}$ and earlier, in 1812, was said to have been "the principal of all the commerce of the city". ${ }^{39}$ The best that can be extracted from this is that Joshua was perhaps employed at some manufacturing place in a busy commercial street, so was engaged in commerce in some fashion. The advert also says he was "known in many islands in the South Seas". On what basis was he travelling around them? He had experience as a sailor, so did that become his principal occupation for a while, or was he trading? No evidence of journeys is known at present, other than to Chile. Then there is the statement that he "was known to Captain Webster of New Zealand". Hazel Petrie has commented:

There were quite a few Websters around New Zealand at the time but I found a letter to the editor referring to the William Webster who was based in the Coromandel as being 'better known as Captain Webster'. That fellow was an American - as opposed to another early settler called William Webster, a Scot who was in Northland as was his brother John. As you will see from his biography ${ }^{40}$ the Coromandel William Webster employed a lot of men in his enterprises so I am thinking that Joshua may have been one of those workers? ${ }^{41}$

If Joshua worked for Webster, he could have done so either before his return to England or after his return to New Zealand. Webster's early business at Hauraki Gulf foundered in 1840 with a loss of land claims, and that could have triggered Joshua's return to England. Webster recovered some of his claims in 1841 but his activities were then reduced to mining and sawmilling on the Coromandel peninsula, though Joshua could still have had dealings with him during that later period. Webster left New Zealand in 1847, perhaps prompting Joshua's move to Chile.

It seems clear from testimony in the probate papers that Joshua returned to New Zealand for a third time from Chile and settled back into Māori society. His end is then presumed by those 1865 probate court hearings in England. They provide a detailed account of what was known of his later days and of the (unsuccessful) efforts made to trace him. The complete court summary is important to a full understanding of what was possibly known about Joshua, and is as follows:

In Her Majesty's Court of Probate

In the Goods of Joshua Mewburn deceased

Case for Motion

In the month of January 1833 Joshua Mewburn who then lived at Matson's Cottage, Kingsland Road in the County of Middlesex left England for New Zealand. 
His father (inserted: Henry John Mewburn) died on the $21^{\text {st }}$ May 1836 leaving by his Will which was proved in the Prerogative Court of Canterbury on the $12^{\text {th }}$ August in that year bequeathed the residue of his Estate to Trustees for his Wife Jane Mewburn during her life and after her death to be equally divided among her children.

Joshua Mewburn returned to England on the $3^{\text {rd }}$ April 1841 and sailed again for New Zealand on the $19^{\text {th }}$ June 1842.

Jane Mewburn died on the $16^{\text {th }}$ February 1856 and it then devolved upon Barak Mewburn the Brother of the said Henry John Mewburn and the surviving Executor named in his Will to divide his Residuary Estate.

As neither the said Barak Mewburn nor any member of the family then in England had heard from the said Joshua Mewburn or his Brother Augustus William Mewburn for many years the said Barak Mewburn on the $28^{\text {th }}$ April 1857 wrote to their Brother Henry John Mewburn then residing in Sydney in Australia forwarding to him a Power of Attorney authorizing some person in England to receive his share of the said residue and requesting him to make inquiry for his Brother and forward the result.

In the month of September 1857 the said Barak Mewburn received by post from the said Henry John Mewburn the letter being the Exhibit marked A. annexed to an Affidavit made by him and others and filed in the Registry.

In this letter the following passage occurs:

"I have not heard anything of Bill" (thereby meaning the said Augustus William Mewburn) "since he left Sydney in April 1855 for the Turon Diggings in company with Louis de Coudre - I have done all I can in advertising him likewise poor Josh" (meaning thereby the said Joshua Mewburn) "Several persons that I know who have left Sydney for New Zealand I have instructed to make every inquiry there, but as yet no tidings. Please God should I hear of either Josh or Bill I will let you know immediately".

On the $9^{\text {th }}$ January 1857 Samuel James Mewburn the Son of the said Barak Mewburn wrote to his cousin the said Henry John Mewburn upon several family matters and begged him to let him have any tidings he might have obtained respecting his Brothers Augustus William Mewburn and Joshua Mewburn and in the month of December 1857 he received by post from the said Henry John Mewburn a letter namely the Exhibit marked B. annexed to the before mentioned Affidavit.

This letter contains the following passages:

"We have had no intelligence of William since he left for the Diggings in April 1855. I have used every endeavour to find his whereabouts but no success as yet - I have been more successful respecting poor Josh alias Moko" (meaning thereby the said Joshua Mewburn) "and am led to believe that he is still living in New Zealand at a place called Waipar near Waicataio about fifteen miles from Auckland New Zealand. The information I obtained in the first place was by advertising for intelligence of Joshua Mewburn (alias Moko) who was tattooed and known in New Zealand which led to the following information. A. W. Buckingham who has a family that gives Concerts in Sydney used to do the same in Auckland and knew Moko sixteen years [c1841] ago - he tells me he was living and well three years since [c1854] and quite settled down amongst the Mouris (New Zealanders). He said he was subject to rheumatism in the cold season of the year and had lived near the Hot Springs ${ }^{\dagger}$ and that he never would care to leave that Country for the Mouris had too great regard for him. They looked upon him as something uncommon a supernatural. He occasionally comes down to Auckland about once or twice a year in a large Canoe with about 50 New Zealanders bringing down produce and taking back Blankets, Calico, Tobacco \&c \&c. Moko stands foremost part of the Canoe on the look out as their Captain giving orders to the steersman all the rest pulling with their paddles he jabbering amongst them in Mouri and going on with his hanky panky tricks for their amusement. The next information I obtained was from John Hatfield a gentleman who has property in Auckland who knew him well and has met him many times at the Theatre in Auckland. He last saw him three years ago [c1854]. He tells me to write to a Johnny Cowell Post Office Waipar and he will be able to find him out as he and Moko have both been known in New Zealand for more than twenty years [before 1837]. I now intend to advertise for him in a New Zealand paper a Mr. Williamson is the Editor of and a fellow passenger to these Colonies with Mr. Parkes Editor of the Sydney Empire who lived opposite to me in Hunter Street. So expect to be able to gather some information further through this source whether he is now living or dead. Whatever I hear I will let you all know direct".

No further information respecting Joshua Mewburn has been received by Barak Mewburn, or Samuel James Mewburn from the said Henry John Mewburn who himself died on or about the $22^{\text {nd }}$ December 1858.

In the month of October 1859 Barak Mewburn received by post from Sydney a letter in the handwriting of the said Augustus William Mewburn which letter is the Exhibit C. annexed to the before mentioned Affidavit.

In one part of this letter the said Augustus William Mewburn says: "I was in Burnt Creek Victoria when I received a letter from Fanny" (meaning the Wife of Henry John Mewburn) "informing me of the death of poor Mother and John" (meaning by John the said Henry John Mewburn).

In another part he says:

"Since I have been back I have made enquiry's about Josh - there's a man answering his description a tradeing on the East Coast of New Zealand now - I don't know the best way to get at him whether to send a letter or go myself and find him. I believe one way would be just as difficult as the other - the expence of going to New Zealand and back again would be a good bit of money so I think by sending a letter there to a person that knew him when he was there before we may get some information from him of his whereabouts. I will do all I can to find him".

On the $10^{\text {th }}$ July 1862 Barak Mewburn sent by post to New Zealand a letter (the Exhibit marked D. annexed to the Affidavit before mentioned) which he enclosed in an envelope (the Exhibit E. annexed to the said Affidavit) and on which envelope he wrote the following direction:

\footnotetext{
${ }^{*}$ This is a little problematic. The only likely places that correspond are the Waipa Valley near Waikato, but Waipa lies 150 miles from Auckland, not 15.

'Though today's resorts of Taupo, Okoroire, or Rotorua are all quite far from Waipa - 70 miles or more.
} 
"Joshua Mewburn known by the Natives as Jemmy Moko and tattooed in the face and well known to Johnny Cowel Post Office Waipar near Waicatio 15 miles from Auckland New Zealand. If dead all expences will be paid on the return letter."

The foregoing direction was gathered from the Exhibit B. and was written in the hope that the letter might reach the said Joshua Mewburn but the letter and envelope were returned to Barak Mewburn in an official Envelope (the Exhibit F. annexed to the said Affidavit) and reached him in the month of May 1863 with a memorandum written on the Envelope directed by Barak Mewburn as follows:

"Reported by Mr John Cowell to have died some time ago Waipa Jno. Morgan Post Master Nov 1862".

In the month of August 1862 the said Barak Mewburn received by post from the said Augustus William Mewburn a letter (the Exhibit G. annexed to the said Affidavit) in which the following passages occur:

"I am afraid that we shall never hear anything now of poor Joshua. I thought once that I had got a clue to him but no it was not him. I think that he must have died or else we should have heard of him ere this. I made every enquiry but can get no tidings of him in the least. Now if he had been any where about Auckland or the Bay of Islands I may have heard something about him. I found out a gentleman by means of the Webbs who had been living in Auckland a great many years. He said there was a man answering his description - he said he would make enquiry about him for me. The next time I met him he told me that was not the same party. His opinion was that he had died or he must have seen him the number of years he had been living in that Country. It's my belief that if he be dead we shall get no authentic account of it".

Barak Mewburn has not received any further communication from the said Augustus William Mewburn.

On the $26^{\text {th }}$ February 1864 the Solicitor of the said Barak Mewburn sent by post to a firm of Merchants at Auckland requesting them to direct their Solicitor to institute inquiries for the said Joshua Mewburn and to forward the best evidence they could obtain respecting him but he has received no reply to such letter.

Barak Mewburn, Samuel James Mewburn and Elizabeth Ashley and Louisa Trenery the Sisters of the said Joshua Mewburn have all deposed in the said Affidavit that they believe him to be dead.

Counsel will move the Court to decree Letters of Administration of the Effects of the said Joshua Mewburn to be granted to the said Elizabeth Ashley wife of James Ashley his natural and lawful Sister and one of his next of kin on her swearing that he had died in New Zealand in or since the year 1855 a Bachelor, without a parent and Intestate. ${ }^{42}$

These papers make it clear that Joshua was living in New Zealand after the Chile episode, and that by two accounts he was alive there around 1854. There are no comments that place him any later. That is the end of Joshua's tale in the records, presumed dead in 1855 . Even so, it suggests that he identified as a Pākehā-Māori to the end - over twenty years.

\section{Joshua as a Pākehā-Māori}

Comment on this is dangerous territory for a non-New Zealander, but questions inevitably arise about Joshua's status and conditions of life.

Joshua never actually described himself as a Pākehā-Māori and may not have even been aware of the term. When he first arrived in New Zealand the term did not have the relatively settled meaning it now has. Indeed, the Māori had not then reconciled themselves to being known as Māori (rather than members of a particular tribe or iwi). Bentley, in his book Pakeha-Maori, even felt compelled to devise a set of categories to describe the differing forms of engagement with Māori society displayed across the range of Pākehā-Māori. ${ }^{43}$

What can we infer about Joshua's identity and his sense of self? The principal account states that he was first robbed and left naked at the Bay of Islands. After a few days, he was found and taken in by Māori. We do not know exactly where that was, though it can hardly have been more than ten miles from the Bay of Islands, neither do we know the name of the hapū (tribal unit) that initially provided succour. There are suggestions that he was enslaved. Slavery in a Māori context was quite different to that in the European context of that time. Slaves were not simple commodities to be bought and sold. They were often captives, taken in war, and held almost in compensation or reparation (utu) for losses sustained during hostilities. They lived relatively normal lives within the community, though mostly (but not always) in a subservient position, and they did contribute significantly to the labour force. As Petrie puts it: "The people referred to as slaves in English were generally war captives forced to perform not only the unpleasant work despised by people of higher status, but also that which was most damaging to tapu and mana - such as making fires and cooking food." ${ }^{44}$

However, the possession of slaves contributed to mana, the esteem that accrued to the local chief. A Pākehā "slave" was less likely to have been captured in war but could contribute to mana presumably through rarity and curiosity value. Joshua was, at the outset, one such curio and probably something to be displayed as such. There are hints that he was passed around and lived in several communities. That seems to square with the notion of him as a captive or slave and being used as an item of value in intertribal reparations where "captives might be gifted as utu for crimes committed by others or for loss of face". ${ }^{45}$ But that was hardly true of the second period after he returned again to New Zealand in 1842 and when, latterly, he apparently assumed a leadership position on trading visits to Auckland. During the first eight years did his status change? Did he assimilate and become "more Māori" or at least more acceptable? Did he acquire mana? 
Those who housed him initially would hardly have continued to do so from purely altruistic, charitable motives. He was a cost to the community, but he may have paid for his keep in entertainment value. Pākehā could be kept by a chief almost like pets. In time, Joshua learnt the language and customs. It is possible that he rapidly began to empathize with his keepers. He was a teenager when this began and he may have succumbed to Stockholm syndrome and developed a psychological bond with his "captors". With such a bond, and language skills, he could have become a material contributor to the community.

At his court appearance in London, the story of his capture changed significantly. He acquired companions; they were all eaten; he survived by immediately agreeing to be tattooed (a prolonged and extremely painful process where instruments would completely pierce the skin, quite unlike the superficial European style). This story is likely to be an embellished version suited to Joshua's exhibition appearances. However, the timing of the tattooing is interesting. If it did happen early in his Māori service, it could have been done to enhance the value of his head as a potential trade item (the moko, or tattoo, itself possessing mana). Alternatively, the situation might have been similar to that of another notable Pākehā-Māori, Barnet Burns, where the chief requested "that I should allow myself to be tattooed after the manner of his subjects. I asked him what was the reason for wishing it. He told me it was merely to make sure I should stop along with them, bring up trade, fight for them, and in every way make myself their friend." ${ }^{\prime 46}$

Whatever the reason, Joshua would have gained mana by submitting to the process and that, in turn, would have reflected well on the chief he was serving. There is no reason to doubt Joshua's account that he engaged in tribal warfare. Bentley accepts this and describes Joshua as a Pakeha toa - a fighting Pākehā. ${ }^{47}$ If he was a good fighter he would again have gained mana and his status, and that of his chief, would have been enhanced further.

Once Joshua had some command of the Mãori language his usefulness would have become more apparent because he could act as an intermediary in dealings with Europeans. Unlike the typical mariner, Joshua had a decent education (he may not have been the sharpest knife in the Mewburn family silver canteen, but still he had been schooled and was from a family in commerce) and would have been capable of acting not just as a translator, but as a knowledgeable intermediary in dealings with traders. His value and status would have increased accordingly. Frederic Maning (an earlier, self-aggrandizing Pākehā-Māori) suggests in Old New Zealand ${ }^{48}$ that in the earliest days "the value of a pakeha to a tribe was enormous", especially one who could acquire muskets. "A pakeha trader was therefore of a value say about twenty times his own weight in muskets ... a second-rate pakeha, not a trader, might be valued at say his weight in tomahawks; an enormous sum also". Joshua, as a warrior with a moko and an able intermediary, though not a trader, must have been somewhere in the middle of this scale. The downside to increased status was that it probably led to a greater binding to whatever chief he served by that time. Any desire for freedom would have been correspondingly difficult to achieve, though evidently it did eventually happen. Did he literally escape? The accounts make no mention of such a thing, other than the otherwise unexplained comment about him having spent some fourteen months alone in the bush. Might that have been when he made his way to where Webster had his operations at Coromandel? Somehow during the first eight years it seems likely that he did make his way from the Bay of Islands to the Auckland area where shipping back to England was more practicable.

It is clear from his return to England that at some point the notion of his being a slave evaporated. He had been able to arrange his own passage to England - presumably working it as a seaman since he can have had few resources to purchase it. That squares with the registration of his seaman's ticket after his return. This outcome, of being a free man, is even clearer in his ability to have been accepted back into Mãori society after his return to New Zealand. Changes in society may have eased this process. Early contact in the decade or more prior to Joshua's arrival had stimulated demand for local trade goods; muskets were sold in exchange, and facilitated captive-taking during the Musket Wars of 1818-1839 (in the latter part of which Joshua participated); the captives provided the labour needed to provide trade goods (especially flax-based and kauri wood) and to handle the "massive agricultural and economic expansion among the Maori of the North Island throughout the decade before $1840 "{ }^{49}$ As more ships arrived throughout the 1830 s and the novelty wore off, there was a decline in demand for the local goods, and therefore the need for labour. Simultaneously, a rise in missionary activity questioned and campaigned against "slavery", and the influx of colonists after 1840 further altered matters. By the late 1830s we may imagine that the desire to keep Joshua as a "slave" may have diminished and been replaced by a form of coexistence.

What is reasonably certain is that his time back in England demonstrated to him that he would not be held in much esteem in his homeland. A failed business venture, the need to put himself on public display, the humiliation of public drunkenness and a night in the cells must have convinced him that the Mãori were truly his people. That, surely, prompted his return to New Zealand and a life that was by then more familiar to him. Quite how he managed to gain a place on the Jane Gifford, though, among a group made up largely of weavers from Paisley and other Scots, is unknown.

Joshua managed to assimilate again into Māori society on his return, despite turning up with a Pākehā wife. It is curious that Joshua, in England, denied having a Māori wife (though, as Petrie has commented, if they had not been married by a missionary then perhaps he felt 
justified in such a claim). Māori hospitality commonly offered men the comfort of a wife, and a warrior sporting the moko might have been multiply blessed. Remarkably, some insight into this appears in an early history - Thomson's Story of New Zealand of 1859. Joshua is not named but it can only be him when Thomson says:

One unemployed tattooed Pakeha Maori visited England, and acted the part of a New Zealand savage in several provincial theatres. Here he married an Englishwoman who accompanied him to New Zealand, but she eloped with a Yankee sailor, because the tattooed actor's old Maori wife met him and obtained an influence over him the white woman could not combat. ${ }^{50}$

We know that Joshua's marriage to Frances was a sham, but this introduces some clarity to Frances' escape (though hardly something Joshua would have stood in the way of). The "Yankee", however, was most likely an American whaler so would not have taken her back to England. Her story has yet further unknown twists. Thomson's reference to Joshua as unemployed is intriguing but might just mean that he had indeed worked for William Webster (presumably after having freed himself from "slavery") and suffered in the collapse of Webster's businesses around 1840.

There is also one more newspaper account to conjure with. The Daily Southern Cross in 1862 quoted items from the Auckland Times of twenty years earlier in which, on 25 October 1842, it commented that "The Jane Gifford drops down on Tuesday to Coromandel Harbour, to take up spars from Mr. Webster's station. This vessel we understand proceeds hereafter to China." ${ }^{\prime 51}$ We can only suppose, but might Joshua have gone with them to renew an acquaintance with Webster? The timing gave him two weeks to sever connection with his wife Frances! There is yet one further snippet, again less well attributable, that might say something about Joshua's return. George Angas, in his account of a journey through New Zealand, commented on 16 October 1844 that:

Near Whakatumutumu, [today, around Eight Mile Junction] on the Mokau, there resides a European or Pakeha Maori, who has become almost more savage than the natives themselves: he is partially tattooed, and clothes himself in a mat or blanket; he has at least six wives and adopts all the habits and manners of the Maori people. ${ }^{52}$

The date is appropriate, as is living on the Mokau, so it could be Joshua. Bentley takes this account as referring to a "rangatira Päkehä" - one who has achieved chiefly status (though he did not link it to Joshua). ${ }^{53}$ As a warrior and one who was tattooed, Joshua may indeed, by then, have gained respect and achieved such a status. That would account for the statements appearing in the probate papers of the Māoris having "great regard for him", and of him, some years later, coming down to Auckland in canoes for trading purposes and apparently acting as a guide, or "captain", from the prow of the leading canoe. It seems that he never set up directly as a trader to benefit from his Māori associations but instead acted as an intermediary to the traders to the benefit of those he lived with.

By the 1840s and 1850s wheat was being grown and milled by the Māoris in the Waikato district and was regularly being taken to Auckland by canoe, ${ }^{54}$ so it is entirely plausible for Joshua to have been part of such trips. They would also have enabled him to indulge in his one remaining western luxury, the theatre, mentioned in the court papers by John Hatfield.

Other accounts from contemporaneous histories by such as Polack, ${ }^{55}$ Heaphy, ${ }^{56}$ Wakefield, ${ }^{57}$ and Sherrin and Wallace ${ }^{58}$ lack any mention of Joshua or anecdotes that might plausibly relate to him.

Exactly where he lived in the last part of his life is uncertain, though the mention of "hot springs" in court evidence takes him well to the east of Whakatumutumu and even east of the Waipa Valley where he was last sought. A canoe journey from these regions might have been made via the Waikato River, plus a short sea passage round to Manukau Heads and into Big Bay. That river tracks back all the way to Taupo with its noted hot springs. Orakei Korako, though, is less far from Auckland along the Waikato, was less densely populated than the Taupo area, and also has fine geothermal features, so may be the principal candidate for where Joshua died.

Whether he had children is not known. Might there be descendants with a whakapapa as well as a genealogy? A final tantalizing glimpse comes in another anecdote from Thomson:

In 1852, when travelling to Taupo with Major Hume and Captain Cooper of the $58^{\text {th }}$, we encountered a good specimen of this almost extinct class [the Pākehā-Māori]. His residence resembled a whaler's hut, and stood on the bank of a beautiful river, in the middle of a peach orchard. He welcomed us into his house, and told his native wife to prepare food for us. After we had finished our repast, he called five half-caste children forward ... . ${ }^{59}$

The timing and location - 1852 and near Taupo in that area of "hot springs" - are appropriate, and there were few Pākehā-Māori living remotely. Might Joshua have ended his life in that idyll? Some context for his existence is given by Thompson, just before that anecdote, who offered the following numbers for Pākehā-Māori (Table 1). 
Table 1. Numbers of Pākehā-Māori.

\begin{tabular}{lc}
\hline Date & Number \\
\hline Before 1814 & 6 \\
1827 & 15 \\
1830 & 50 \\
1835 & 100 \\
1840 & 150 \\
1845 & 50 \\
1850 & 15 \\
1853 & 10 \\
\hline
\end{tabular}

Note: The provenance for the numbers is not given so their accuracy may be uncertain, though the pattern is the interesting

feature.

Many of these people lived with the Māori for fairly short periods and it is interesting to see that the "possession" of a Pākehā was widespread by 1840 , with most tribes hosting one. However, the numbers dropped off dramatically with the onset of large-scale colonization and, presumably, the growing threat to Māori society. It was no longer amusing to have a Pākehā pet. Joshua, though, demonstrated his absolute commitment to the Pākehā-Māori lifestyle, embracing it to the last and living through to the end of its run.

\section{Conclusion}

A chronology for the information that has been turned up summarizes the context for what we know of Joshua Mewburn (Table 2).

Table 2. Chronology of Joshua Mewburn's life.

\begin{tabular}{|c|c|}
\hline Date & Event \\
\hline 27 Jan 1833 & Joshua articled to Captain Plant (cannot have been 27 Feb as in newspaper article). \\
\hline 1 Feb 1833 & Marquis of Lansdown sailed for the Southern oceans (returned 20 Dec 1836 with 500 casks of whale oil). \\
\hline $1 \mathrm{Jul} 1833$ & $\begin{array}{l}\text { After a five-month voyage, the Marquis of Lansdown made landfall at Bay of Islands, New Zealand. Joshua robbed then rescued/ } \\
\text { enslaved by Māoris. }\end{array}$ \\
\hline 13 Jul 1833 & Marquis of Lansdown continued her journey. \\
\hline $1833-1840$ & The first phase of Joshua's life in New Zealand - initially "enslaved". \\
\hline 19 May 1836 & Father, Henry John, died. $£ 100$ bequeathed to Joshua. \\
\hline Late 1830 s & Did Joshua meet up with Captain Webster? \\
\hline 3 Apr 1841 & Joshua returned to London (according to probate papers) after eight years away. \\
\hline 3 April 1841 & The John Renwick, under Captain Morgan, arrived at Gravesend from Sydney, NSW. \\
\hline 27 Aug 1841 & Joshua ended partnership in tobacconist business. \\
\hline 20 Oct 1841 & Joshua married Frances McDonald. \\
\hline $1841-42$ & Public performances of "the dreadful sufferings of Joshua Newburn, nine years captive in New Zealand". \\
\hline 21 May 1842 & London court appearance - drunk and disorderly. \\
\hline 18 Jun 1842 & The barque Jane Gifford departed from Glasgow with Joshua and Frances. \\
\hline \multirow[t]{2}{*}{9 Oct 1842} & After a four-month voyage, Jane Gifford arrived at Auckland. \\
\hline & A. S. Thomson's (1859) account of Joshua's return and split from Frances. \\
\hline 16 Oct 1844 & George Angas told of a rangatira Pākehā-Māori living on the Mokau River. \\
\hline $1840 \mathrm{~s}$ & Joshua may have spent time travelling around the South Seas islands. \\
\hline \multirow[t]{2}{*}{ February 1848} & Joshua was said to be living in Santiago, Chile. \\
\hline & John Hatfield "met him many times at the Theatre in Auckland"! \\
\hline 1852 & Was possibly sighted by Thomson on his way to Taupo. \\
\hline About 1854 & Said to be in NZ according to A. W. Buckingham and John Hatfield, and living near "Hot Springs" (Orakei Korako or Taupo?). \\
\hline 1855 & The year of Joshua's presumed death. \\
\hline 16 Feb 1856 & Mother Jane (now Glover) died. \\
\hline 28 Feb 1857 & Advert placed in the Sydney Morning Herald seeking information. \\
\hline 1865 & Probate granted on the grounds of Joshua's presumed death. \\
\hline
\end{tabular}

The facts of Joshua's life have been reasonably well established and some insight gained into the progress of his life. His arrival in 1833 undoubtedly made him an early, if inadvertent, settler in New Zealand so his exploits are an important element in the country's pre-colonial history, and in the first decade or so of its colonial period. Joshua lived as a Māori, and among them, for over twenty years, a greater time than most other Pākehā. Both initially and latterly he appears to have lived exclusively within the Māori culture, even possibly achieving rangatira status, with moko and a warrior background. He may have been one of New Zealand's truest Pākehā-Māori, an exceptional example from early times. He was one of a small number when first enslaved and was one of the very last of the type when he died. 
Information about him is fragmentary and he lived largely out of the public gaze, apart from his brief return to London. He may have influenced the communities in which he lived to some small extent and, by acting occasionally as a go-between in trade between some Māori groups and the burgeoning Pākehā colonists, he must have helped a little in developing a degree of understanding between the cultures. However, in the context of the development of modern New Zealand and cross-cultural appreciation, his role was slight. His life in New Zealand spanned the main period of the Pākehā-Māori phenomenon and he is interesting, even in that context, for being an exception; a rarity, someone who demonstrated complete commitment and chose to live differently to the end.

\section{Acknowledgments}

I am grateful to Dr Hazel Petrie for commenting on this work and bringing material to my attention that, from England, I would not have discovered.

\section{Citation information}

Cite this article as: Macdonald, Ian G. (2018) Joshua Mewburn - accidental New Zealand pioneer of 1833 and Pākehā-Māori. Journal of Genealogy and Family History. 2(1). pp. 37-51. http://dx.doi.org/10.24240/23992964.2018.1234514

\section{References}

1. Macdonald, Ian G. Mewburn and Meaburn - the people - their family tree. http:// mewburn.one-name.net.

2. Macdonald, lan G. Mewburn \& Meaburn family history site. https://www.mewbur nandmeaburn.com.

3. Macdonald, Ian G. (2017) Mewburn: London silversmiths. The Journal of Genealogy and Family History. 1(1). pp. 1-12. http://dx.doi.org/10.24240/23992964.2017. 030101

4. Baptisms (PR) England. 1817. St Luke, Finsbury. 27 Mar 1817. MEWBURN, Joshua. Collection: Births and Baptisms, London, England, 1813-1906. www.ancestry.com/.

5. Baptisms index (PR) England. 1817. St Luke, Finsbury, London. 03 Aug 1817 MEWBURN, Joshua. Collection: England Births and Christenings, 1538-1975. https://familysearch.org/pal:/MM9.1.1/NP7G-WMN.

6. Goldsmiths' Company. Apprenticeship and Freedom Index, 1578- The Black Book'. London: Goldsmiths' Library.

7. Merchant Seamen, Britain, 1835-1857. MEWBURN Josh. GRO Series BT 114. www. findmypast.co.uk.

8. Testamentary records. England. Principal Registry, London. 1865. MEWBURN, Joshua. Collection: England \& Wales, National Probate Calendar (Index of Wills and Administrations), 1858-1966. www.ancestry.com/

9. National Archives (Great Britain). 1865. Testator: Mewburn, Joshua. Reference: J 121/ 1060. http://discovery.nationalarchives.gov.uk/results/r?_q=Joshua+Mewburn.

10. Times. (1841) An extraordinary case. The Times. 11 November. p. 5. https://www. thetimes.co.uk/archive/.

11. Courier. (1842) English extracts: an extraordinary case. Courier, 15 April. p. 4a. http:// trove.nla.gov.au/.

12. Colonial Observer. (1842) Extraordinary adventure in New Zealand. Colonial Observer. 3 September. p. 6b. http://trove.nla.gov.au/.

13. Whakatane and District Historical Society. (1981) Joshua Newborn - a tatooed Pakeha. Historical Review, 29(1). pp. 54-55.

14. Petrie, Hazel. (2016) Comments (Mewburn and Meaburn - the people - thei family tree). Email to lan G. Macdonald, 15 September.

15. Bentley, Trevor William. (2007) Images of Pakeha-Māori. A study of the representation of Pakeha-Māori by historians of New Zealand from Arthur Thomson (1859) to James Belich (1886). Unpublished PhD thesis, University of Waikato. p. 88. https://research commons.waikato.ac.nz/handle/10289/2559.

16. Bentley, Trevor. (2010) Cannibal Jack. The Life and Times of Jacky Marmon, a PäkehäMāori. North Shore, NZ: Penguin Books.

17. Illustrated London News (1842) Police. Worship Street. Joshua Newborn [sic]. Illustrated London News. 21 May. p. 26b. http://gale.cengage.co.uk/product-high lights/history/illustrated-london-news.aspx.

18. New Zealand Colonist and Port Nicholson Advertiser (1842) Worship Street. Joshua Newburn. New Zealand Colonist and Port Nicholson Advertiser. 15 November. Vol. I Issue 31, p. 3. https://paperspast.natlib.govt.nz/.

19. University of Hull. '558.10 Marquis of Lansdown.' British Southern Whale Fishery - Voyages. http://bswf.hull.ac.uk/Output.php?SHIP=Marquis+of+Lansdown\&SUBMIT=Submit.

20. Rhys, Richard and Joyce Chisholm. (1992) Bay of Islands Shipping Arrivals and Departures 1803-1840. Wellington, NZ: Paremata Press.

21. Pickering, T. Moko Wairua, a New Zealand captive. Playbill, c.1842. London. Ref. B039-022. Wellington, NZ: Alexander Turnbull Library.

22. Lloyd's List. (1841) Gravesend. 03 Apr 1841. John Renwick from Sydney, NSW. Lloyd's List, 5 April. No. 8477. p. 1. https://www.britishnewspaperarchive.co.uk/.
23. Testamentary records. England. Canterbury. 1865. MEWBURN, Henry John. Collection: Wills and Probate at the Prerogative Court of Canterbury - pre-1858. Ref. PROB 11/1865/ 446. Kew: The National Archives. Downloadable at http://www.nationalarchives.gov.uk.

24. London Gazette. (1841) Notices. London Gazette. 31 August. Issue 20012; p. 2005. https://www.thegazette.co.uk.

25. Marriages (PR) England. Bermondsey, Surrey. 20 October 1841. MEWBURN, Joshua and McDONALD, Frances Ellen. St James, p. 248; No 495. Collection: Marriages and Banns, London, England, 1754-1921. www.ancestry.co.uk/.

26. Burns, Thomas. (1840) 'Appeal on behalf of the Paisley New Zealand Emigration Society.' Emigration to New Zealand. Report of the speeches delivered by the Rev. Dr Burns and others at the meeting in the Philosophical Hall, Paisley on Monday, the $27^{\text {th }}$ June, 1840. Collection: The Pamphlet Collection of Sir Robert Stout. Wellington, NZ: Victoria University of Wellington. http://nzetc.victoria.ac.nz/tm/ scholarly/tei-StoutNewZ-t2-body-d1.html.

27. Standard. (1842) Extract of a letter from Paisley. Standard. 5 April. No. 5539, p. 1c. www.britishnewspaperarchive.co.uk.

28. Staffordshire Advertiser. (1842) Emigration - Paisley. Staffordshire Advertiser. 18 June. Vol. 48. p. 2g. www.britishnewspaperarchive.co.uk.

29. Glasgow Herald. (1842). Emigration. Glasgow Herald. 2 May. No. 4096, p. 3h. https:// news.google.com/newspapers?nid=GGgVawPscys $C \&$ dat $=18420506 \&$ printsec $=$ front page\&hl=en

30. New Zealand Department of Internal Affairs File, ref: 1845/2092: microfile no 1.2 Certificate of Final Departure

31. Lloyd's List. (1842) Clyde. 19 Jun 1842. Jane Gifford, Paul, New Zealand. Lloyd's List. 22 June. No. 8824, p. 2 b.

32. Whyte, A. transcriber. (1998) Jane Gifford - 1842. http://www.newzealandgenweb. org/index.php/regions/auckland/44-source-records-auckland/52-passenger-list-ofjane-gifford-glasgow-9-june-1842-to-auckland.

33. GENi. (2017) 'New Zealand Settler Ships - Jane Gifford 1842', New Zealand Pioneer Families 1800-1900. https://www.geni.com/projects/New-Zealand-Settler-ShipsJane-Gifford-1842/18446.

34. Graham, Robert. (1842) Journal of a passage from Greenock to Auckland New Zealand on board the 'Jane Gifford'. ID: NZMS 1018 (New Zealand manuscripts). Auckland, NZ: Central City Library.

35. Burials (PR) England. Shoreditch, London. 14 June 1848. MEWBURN, Frances Ellen. Collection: England Deaths and Burials, 1538-1991. www.ancestry.co.uk/.

36. Sydney Morning Herald (1857). Advertising. Sydney Morning Herald. 28 February. No. 5848 - Vol. 38, p. 1. http://trove.nla.gov.au/.

37. Ville, Simon P. and Judith Kearney. (1990) Transport and the development of the European economy, 1750-1918. New York: Palgrave Macmillan.

38. Caldostrong.com. (2014) Placas de antiguos nombres de calles en Santiago Centro. http://www.caldostrong.com/2014/02/santiago-centro.html.

39. Cavieres, Eduardo F. (2011) 'Mercados y comercio informal en el Chile de la transición de colonia a república'. Nuevo Mundo Mundos Nuevos [online]. Para 42. http://nuevomundo.revues.org/60545.

40. Adams, Patricia. (1990) 'Webster, William 1815-1897.' In: Te Ara - The Encyclopedia of New Zealand. http://www.teara.govt.nz/en/biographies/1w9/webster-william.

41. Petrie, Hazel. (2016) Comments (Mewburn and Meaburn - the people - their family tree). Email to lan G. Macdonald, 15 September.

42. National Archives (Great Britain). 1865. Testator: Mewburn, Joshua. Reference: J 121/ 1060. http://discovery.nationalarchives.gov.uk/results/r?_q=Joshua+Mewburn.

43. Bentley, Trevor. (1999) Pakeha Maori. The extraordinary story of the Europeans who lived as Maori in early New Zealand. Auckland, NZ: Penguin.

44. Petrie, Hazel. (2015) Outcasts of the Gods? The struggle over slavery in Mäori New Zealand. Auckland, NZ: Auckland University Press. p. 40.

45. Petrie, Hazel. (2015) Outcasts of the Gods? The struggle over slavery in Māori New Zealand. Auckland, NZ: Auckland University Press. p. 98.

46. Bentley, Trevor. (2010) Cannibal Jack. The life and times of Jacky Marmon, a PäkehäMāori. North Shore, NZ: Penguin. p. 167.

47. Bentley, Trevor. (1999) Pakeha Maori. The extraordinary story of the Europeans who lived as Maori in early New Zealand. Auckland, NZ: Penguin. p. 92. 
48. Maning, Frederick. (1863) Old New Zealand, a tale of the good old times. By a Pakeha Maori. Auckland: Robert J. Creighton \& Alfred Scales. pp. 17-18.

49. Rhys, Richard and Joyce Chisholm. (1992) Bay of Islands Shipping Arrivals and Departures 1803-1840. Wellington, NZ: Paremata Press. p. 5.

50. Thomson, Arthur Saunders. (1859) The story of New Zealand: past and present savage and civilised. Vol. 1. London: John Murray. p. 300.

51. Daily Southern Cross. (1862) Auckland antiquities. Daily Southern Cross. 16 October. Vol. 18; issue 1634. https://paperspast.natlib.govt.nz/.

52. Angas, George French. (1847) Savage life and scenes in Australia and New Zealand. Vol. 2. $2^{\text {nd }}$ ed. London: Smith, Elder \& Co. p. 82.

53. Bentley, Trevor. (1999) Pakeha Maori. The extraordinary story of the Europeans who lived as Maori in early New Zealand. Auckland, NZ: Penguin. p. 165.

54. Petrie, Hazel. (2006) Chiefs of industry. Māori tribal enterprise in early colonial New Zealand. Auckland, NZ: Auckland University Press. p. 228.
55. Polack, J. S. (1838) New Zealand: being a narrative of travels and adventures during a residence in that country between the years 1831 and 1837. London: Richard Bentley. Reprinted 2000, Kiwi Publishers

56. Heaphy, Charles. (1842) Narrative of a residence in various parts of New Zealand. Together with a description of the present state of the Company's settlements. London: Smith, Elder \& Co.

57. Wakefield, Edward Jerningham. (1845) Adventure in New Zealand, from 1839-1844; with some account of the beginning of the British colonization of the islands. 2 vols. London: John Murray.

58. Sherrin, R. A. A. and J. H. Wallace. (1890) Early history of New Zealand. Auckland, NZ: H. Brett.

59. Thomson, Arthur Saunders. (1859) The story of New Zealand: past and present savage and civilised. Vol. 1. London: John Murray. p. 301.

\section{ABOUT THE AUTHOR}

Dr lan G. Macdonald QG, MSc (Genealogical Studies), C.Eng, CITP, FBCS, is a zoologist, explorer, information engineer, quality award assessor, company director and latterly genealogist. lan is a tutor for the University of Strathclyde's online postgraduate genealogy courses and chronicler of the Mewburn family. He is Chairman of the Register of Qualified Genealogists.

Email: iangmacdonald@qualifiedgenealogists.org.

https://orcid.org/0000-0002-0187-1882 